\title{
MANFAAT MEMPELAJARI DASAR-DASAR PERANCANGAN SEBELUM MELAKUKAN PEKERJAAN DESAIN MEDIA KOMUNIKASI
}

\author{
Sugeng Widada ${ }^{1}$ \\ Adi Kusuma Widya Tama ${ }^{2}$ \\ Roy Karno Surbakti ${ }^{3}$ \\ e-mail:sugeng.widada@raharja.info, adi.kusuma@raharja.info, roysurbakti@raharja.info
}

\begin{abstract}
ABSTRAK
Agar dalam melakukan pekerjaan desain dapat dilakukan secara produktif, kreatif dan waktu yang dibutuhkan efisien, dibutuhkan kemampuan mendasar yang memerlukan persiapan melalui pembelajaran dan pelatihan mengenai dasar-dasar perancangan atau istilah yang sering digunakan pada lembaga pelatihan atau institusi pendidikan yang berbasis seni terap disebut Nirmana. Pada dasar-dasar perancangan atau Nirmana yang dipelajari dasar-dasar perancangan dua dimensi atau Nirmana Dwimatra dan dasar-dasar perancangan tiga dimensi atau Nirmana Trimatra. Pada Nirmana Dwimatra yang dipelajari mengenai; unsur atau elemen-elemen dasar dalam perancangan yang disertai pelatihan atau praktek tentang mengatur komposisi unsur rancangan seperti Titik (Dot), Garis (Line), Bidang (Shape) warna (Color). Pada saat mempelajari dasar-dasar perancangan dua dimensi maupun dasardasar perancangan tiga dimensi lebih diterapkan ke membuat hasil karya pengaturan komposis unsurunsur perancangan dengan sekaligus menerapkan prinsip-prinsip dasar perancangan yang dibutuhkan dalam perancangan, seperti penerapan mengenai prinsip Ruang Kosong (White Space), Kejelasan (Clarity), Kesederhanaan (Simplicity), Pusat Perhatian/Kejelasan (Emphasis), Kesatuan (Unity), Keseimbangan (Balance), Proporsi (Proportion), Irama (Rhytm) dan Dominasi (Domination). Dari mempelajari dan memahami dasar-dasar dan prinsip dasar yang dibutuhkan dalam perancangan secara teoritis maupun praktis akan dapat menunjang kreativitas dalam melakukan pekerjaan desain, aratinya segala sesuatu yang di hasilkan akan tercermin nilai-nilai seni yang kreatif dan pelaksanaannyapun waktunya relatif efisien.
\end{abstract}

Kata Kunci: Nirmana, desain dan media

\section{PENDAHULUAN}

Pengembangan kreatifitas sangat menentukan kualitas hasil karya rancangan seseorang, terlebih pihak yang orientasi pekerjannya berhubungan dengan desain atau merancang sebuah karya seni, kreatifitas sangat dibutuhkan. Bukan hanya seperti di Era manualisasi saja, lintas sesuai dengan perkembangan teknologi komputerisasi yang dibutuhkan dalam menentukan kualitas suatu hasil rancangan, bahwa penguasaan secara teoritis maupun praktis tentang dasar- dasar perancangan dua dimensi maupun dasar-dasar perancangan tiga dimensi akan menentukan kualitas hasil karya rancangan karya seni. Kita sependapat bahwa, sebuah media komunikasi agar fungsi dan kegunaannnya dapat efektif dan maksimal

\section{Vol.1 No.1 - Agustus 2015}


sesuai tujuan komunikasi, tentu media tersebut harus memiliki nilai-nilai artistik yang bisa dijadikah daya tarik, sehingga apa yang akan dikomunikasikan "Efektif" akan cepat sampai pada audient. Kata "Efektif" adalah sesuatu yang mudah di ucapkan tapi untuk mewujudkan pada sebuah media komunikasi dibutuhkan tahapan proses pembelajaran dan mempraktekkan ke dalam sebuah karya seni dari pembelajaran dasar-dasar perancangan yang cukup dan disertai referensi yang cukup untuk melakukan pekerjaan desain sebuah media.

\section{PERMASALAHAN}

Kemajuan Teknologi komputerisasi telah menyediakan berbagai aplikasi program dalam menunjang produksi ramcangan sebuah media komunikasi, dari sisi lain dapat dikatakan sebagai penunjang efisiensi dan akurasi dalam bekerja, namun dari sisi lain yang mau mengejakan pekerjaan yang berorientasikan perancangan karya seni, seni murni seni terap dibutuhkan bekal kemampuan kreativitas olah tatarupa agar hasil karya yang kikerjakan dapat terselesaikan seefisien mungkin dan seartistik mungkin, sehingga hasil karya tersebut dapat memberikan daya tarik kepada audient.

Permasalahannya pihak yang akan melakukan pekerjaan rancangan sebuah media komunikasi yang memanfaankan teknologi komputerisasi tidak semua dibekali kemampuan dasar-dasar perancangan yang baik, malah sebagian orang yang sering menggunakan fasilitas aplikasi program omputer grafis tidak tahu atau bahkan tidak kenal dengan materi pembelajaran dasar-dasar perancangan, sehingga jika dituntut ide kreatif yang relative cepat akan mengalami kebuntuan atau kehabisan ide, karena tidak terbiasa kinerja dalam computer grafis menggunakan pertimbangan ide gagasan untuk menghasilkan sebuah karya seni yang kreatif.

\section{PEMECAHAN MASALAH}

Nirmana dipahami sebagai sebuah bentuk yang tidak berbentuk, pengertiannya dalam proses pembelajaran khususnya tugas setiap rancangannya belum mengarah bentuk desain yang lebih spesifik ke dalam bentuk rancangan desain apapun, baru belajar tatarupa menganai pengaturan komposisi elemen dasar menjadi susunan yang kreatif, mempunyai nilai seni yang kreatif. Dalam konteks desain komunikasi visual, Nirmana memegang peranan penting perihal bagaimana menata dan menyusun elemen dasar desain komunikasi visual . Peranan penting lainnya, di dalam nirmana mensyaratkan tatasusun dan tatakelola unsur desain komunikasi visual dalam sebuah perencanaan komposisi yang serasi dan seimbang di dalam setiap bagiannya.

Nirmana didefinisikan pengorganisasian atau tatakelola elemen-elemen visual seperti titik, garis, warna, ruang dan tekstur menjadi satu kesatuan yang harmonis dan serasi. Nirmana dapat diartikan sebagai hasil ide gagasan anagan-angan dalam bentuk dua dimensi atau dwimatra, tiga dimensi atau trimatra yang mempunyai nilai seni dan keindahan. Nirmana disebut juga ilmu tatarupa.

\section{TUJUAN}

Dari permasalahan yang telah disampaikan, artikel pada makalah ini bertujuan:

\section{Vol.1 No.1 - Agustus 2015}


1. Mengenalkan dan menjelaskan arti pentingnya mempelajari ilmu dasardasar perancangan sebelum melakukan perancangan sebuah media berbasis komuniksi visual.

2. Melalui contoh-contoh hasil karya rancangan tatakelola unsur atau elemen-elemen dasar sebuah karya seni akan menambah wawasan dan kekayaan dalam mengembangkan ide kreatif dalam saebuah karya seni.

3. Dapat dijadikan solusi pemecahan penuangan ide kreatif sebuah rancangan media komunikasi visual.

4. Agar setiap rancangan media yang dihasilkan berkualitas, dapat terselesaikan dengan efisien dapat digunakan secara efektif terhadap setiap program komunikasi yang membutuhkan.

\section{PEMBAHASAN}

Arti Penting Nirmana :

Nirmana terbentuk dari dua kata yaitu nir berarti tidak, mana berarti makna, jika digabungkan berarti tidak bermakna atau tidak mempunyai makna. Jika di artikan lebih dalam nirmana berarti lambanglambang bentuk tidak bermakna, dilihat sebagai kesatuan pola, warna, komposisi, irama, nada dalam desain. Bentuk yang dipelajari biasanya diawali dari bentuk dasar seperti kotak, segitiga, bulat yang sebelumnya tidak bermakna diracik sedemikian rupa menjadi mempunyai makna tertentu.

Jika kita telaah lebih jauh, nirmana mirip dengan Tipografi (ilmu_ huruf) yaitu tentang mengorganisasikan sesuatu untuk mencapai kualitas artistik pada sebuah karya seni atau desain. Pada Nirmana juga dibahas dan dipelajari tentang harmoni, keselarasan soal rasa, dan impresi pada sebuah bentuk. nirmana tidak hanya mencakup 2 dan 3 dimensi saja melainkan menjelajah sebuah ruang yang disebut dengan ruang maya.

Ruang maya adalah ruang semu dimana kita bisa berhayal tentang sesuatu yang mebingungkan kita sendiri, dalam artian hayalan tentang sebuah kegilaan bentuk yang sulit kita torehkan dalam wujud media 2 dimensi ( sering disebut dengan nirmana ruang datar / nirmana dwimatra) atau 3 dimensi (sering disebut dengan nirmana ruang / nirmana trimatra).

Pengaplikasian Nirmana mutlak dilakukan dalam semua bidang seni rupa dan desain. Contohnya adalah fotografi, bidang seni ini mempunyai kemampuan melakukan eksekusi ini dengan sangat baik. Kapabilitas fotografi yang merekam obyek setepat-tepatnya dapat kita kacaukan dengan nirmana. Tentu kita sudah biasa jika melihat langit yang jauh yang berwarna biru dan pepohonan yang dekat dengan warna hijau. Namun dengan nirmana, langit dapat kita beri warna panas (orange/ kuning) untuk menciptakan kesan objek tersebut dekat dengan kita. Dan pohon dengan warna dingin (misal biru) untuk memberi kesan objek tersebut jauh dari kita.

Hal ini dapat kita terima karena kita memandang dari nalar bentuk. Disinilah seni dan desain dapat dinilai atas dasar kualitas artistiknya, yaitu menilai segala sesuatunya dari sisi bentuk, bukan dari halhal di luar bentuk (Irama Visual, 2007, hal. 160).

\section{Vol.1 No.1 - Agustus 2015}


Elemen - elemen seni rupa dapat dikelompokan menjadi 4 bagian berdasarkan bentuknya.

- Titik, titik adalah suatu bentuk kecil yang tidak mempunyai dimensi. Raut titik yang paling umum adalah bundaran sederhana, mampat, tak bersudut dan tanpa arah

- Garis, garis adalah suatu hasil goresan nyata dan batas limit suatu benda, ruang, rangkaian masa dan warna.

- Bidang, bidang adalah suatu bentuk pipih tanpa ketebalan, mempunyai dimensi pajang, lebar dan luas; mempunyai kedudukan, arah dan dibatasi oleh garis.

- Gempal, gempal adalah bentuk bidang yang mempunyai dimensi ketebalan dan kedalaman.

Komposisi dari bentuk-bentuk menjadi satu susunan yang baik. Ada beberapa aturan yang perlu digunakan untuk menyusun bentuk-bentuk tersebut. Walaupun penerapan kaidah atau prinsip-prinsip penyusunan tidak bersifat mutlak, namun karya seni yang tercipta harus layak disebut karya yang baik. Perlu diketahui bahwa prinsip-prinsip ini bersifat subyektif terhadap penciptanya.

Dalam ilmu desain grafis, selain prinsipprinsip diatas ada beberapa prinsip utama komunikasi visual dari sebuah karya desain.

\section{- $\quad$ Ruang Kosong (White Space)}

(White Space) Ruang kosong dimaksudkan agar karya tidak terlalu padat dalam penempatannya pada

Vol.1 No.1 - Agustus 2015 sebuah bidang dan menjadikan sebuah obyek menjadi dominan. Ruang kosong penting dalam desain karena sering digunakan untuk berbagai tujuan. Misalnya untuk kejelasan pembacaan dan sekaligus memberikan kesan, seperti kesan profesinal dan sederhana.

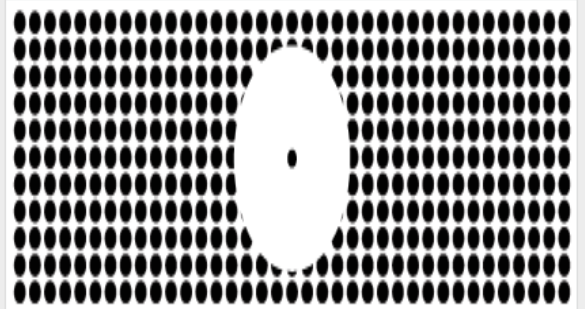

\section{- Kejelasan (Clarity)}

Kejelasan atau clarity mempengaruhi penafsiran penonton akan sebuah karya. Bagaimana sebuah karya tersebut dapat mudah dimengerti dan tidak menimbulkan ambigu/ makna ganda.

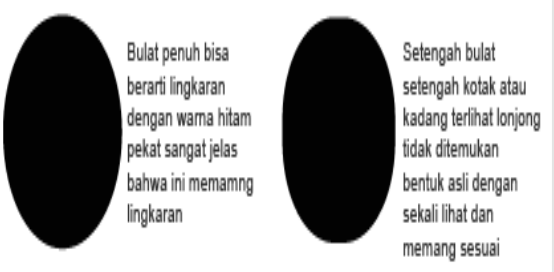

- Kesederhanaan

(Simplicity)Kesederhanaan menuntut penciptaan karya yang tidak lebih dan tidak kurang. Kesederhanaan seing juga diartikan tepat dan tidak berlebihan. Pencapaian kesederhanaan mendorong penikmat untuk menatap lama dan tidak merasa jenuh. 

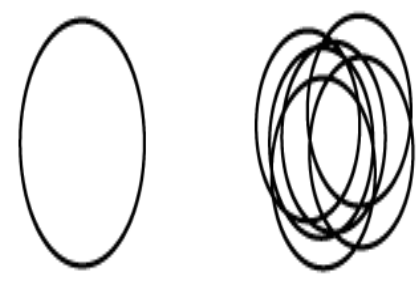

- Emphasis

(Point of Interest)Emphasis atau disebut juga pusat perhatian, merupakan pengembangan dominasi yang bertujuan untuk menonjolkan salah satu unsur sebagai pusat perhatian sehingga mencapai nilai artistic.

\section{0 0000000000000 0000000000000}

\section{Kaidah atau Prinsip - prinsip dasar seni rupa}

\section{- Kesatuan (Unity)}

Kesatuan merupakan salah satu prinsip dasar tata rupa yang sangat penting. Jika tidak terdapat adanya kesatuan dalam sebuah karya rupa akan membuat karya tersebut terlihat menyatu atau cerai-berai, kacau-balau yang mengakibatkan karya tersebut tidak nyaman untuk dipandang mata. Prinsip ini sesungguhnya adalah prinsip hubungan. Jika salah satu atau beberapa unsur rupa mempunyai

Vol.1 No.1 - Agustus 2015 hubungan (warna, raut, arah, dll), maka kesatuan telah tercapai

\section{0 000000000000 00000000000}

- Keseimbangan (Balance)

Karya seni dan desain harus memiliki keseimbangan agar nyaman dipandang dan tidak membuat gelisah. Seperti halnya jika kita melihat pohon atau bangunan yang akan roboh, kita measa tidak nyaman dan cenderung gelisah. Keseimbangan adalah keadaan yang digambarkan oleh suatu obyek yang bekerja saling meniadakan. Dalam bidang seni keseimbangan ini tidak dapat diukur tapi dapat dirasakan, yaitu suatu keadaan dimana semua bagian dalam sebuah karya tidak ada yang saling membebani.

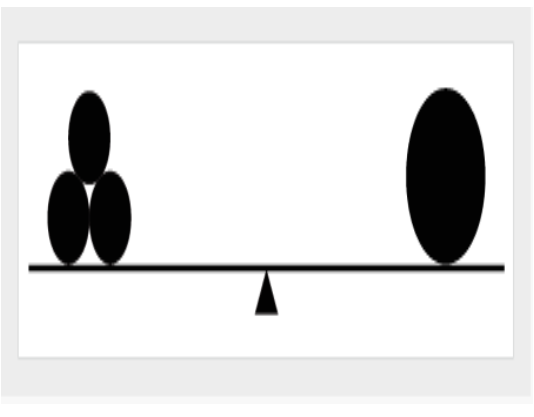

\section{- Proporsi (Proportion)}

Proporsi termasuk prinsip dasar tata rupa untuk memperoleh keserasian. 
Untuk memperoleh keserasian dalam sebuah karya diperlukan perbandingan - perbandingan yang tepat. Pada dasarnya proporsi adalah perbandingan matematis dalam sebuah bidang. Proporsi Agung (The Golden Mean) proporsi yang paling populer dan dipakai hingga saat ini dalam karya seni rupa hingga karya arsitektur. Proporsi ini menggunakan deret bilangan Fibonacci yang mempunyai perbandingan $1: 1,618$, sering juga dipakai $8: 13$. Konon proporsi ini adalah perbandingan yang ditemukan di benda-benda alam termasuk struktur ukuran tubuh manusia sehingga dianggap proporsi yang diturunkan oleh Tuhan sendiri. Dalam bidang desain proporsi ini dapat kita lihat dalam perbandingan ukuran kertas dan layout halaman.

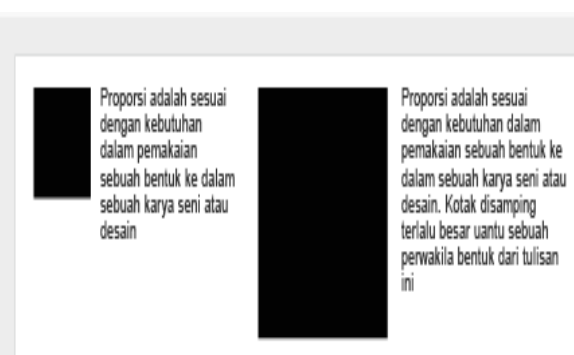

\section{- Irama (Rhythm)}

Irama ada bukan hanya pada seni music saja, melainkan pada Nirmana irama dapat diartikan pengulangan dari bentuk atau unsur lain seperti warna misalnya yang terdapat pada obyek rancangan karya seni dan desain yang menggambarkan pergerakan yang teratur dan terus menerus. Jika dalam bentuk - bentuk alam, kita ambil contoh pengulangan gerak pada ombak laut, gerak dedaunan, dan lain-lain. Prinsip irama sesungguhnya adalah hubungan pengulangan dari bentuk - bentuk unsur rupa.
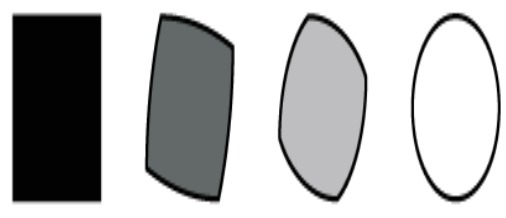

- Dominasi (Domination)

Dominasi merupakan salah satu prinsip dasar tatarupa yang harus ada dalam karya seni dan desain. Dominasi berasal dari kata Dominance yang berarti keunggulan . Sifat unggul dan istimewa ini akan menjadikan suatu unsure sebagai penarik dan pusat perhatian. Dalam dunia desain, dominasi sering juga disebut Center of Interest, Focal Point dan Eye Catcher. Dominasi mempunyai bebrapa tujuan yaitu untuk menarik perhatian, menghilangkan kebosanan dan untuk memecah keberaturan. Biasanya ditengarahi dengan.

\section{Vol.1 No.1 - Agustus 2015}




\section{1 0001000}

Contoh Karya Pengaturan Komposisi Titik (Hitam Putih)
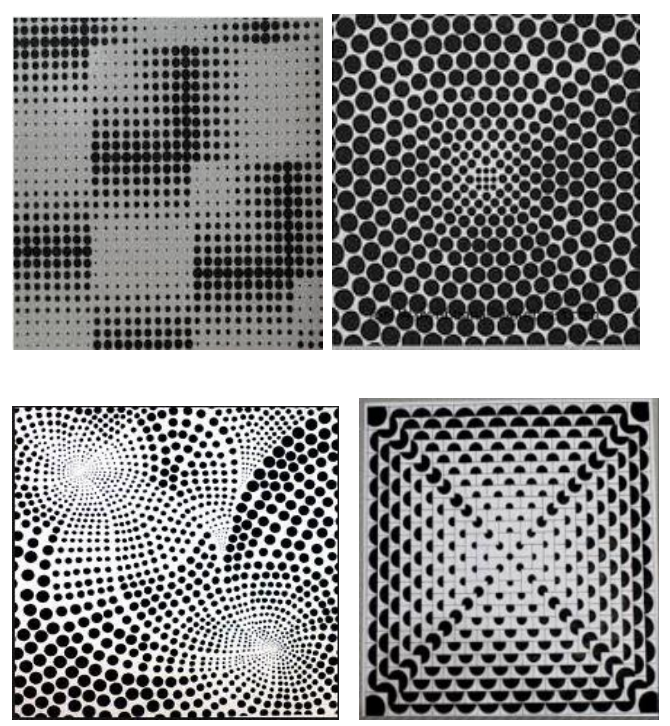

Contoh Karya Pengaturan Komposisi Garis (Hitam Putih)
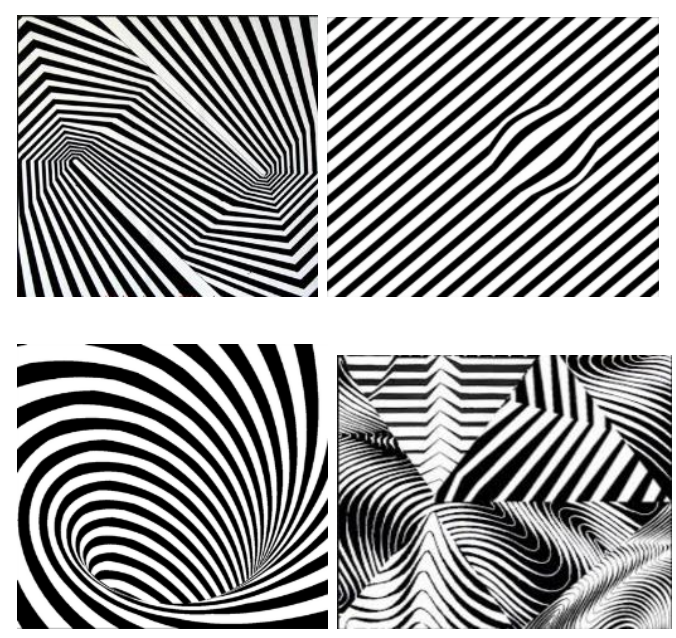

Contoh Karya Pengaturan Komposisi Garis dan Bidang Hitam Putih
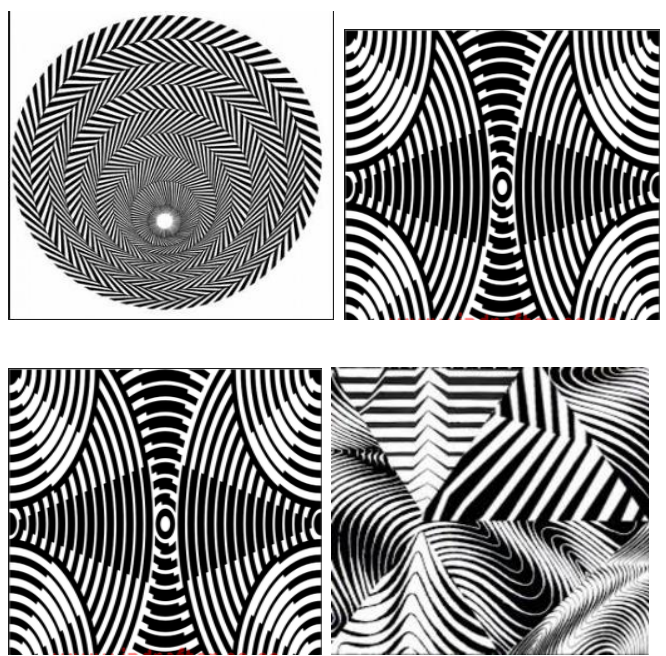

Contoh Karya Teori Warna: Warna Primer, Sekunder dan tersier (Berwarna)

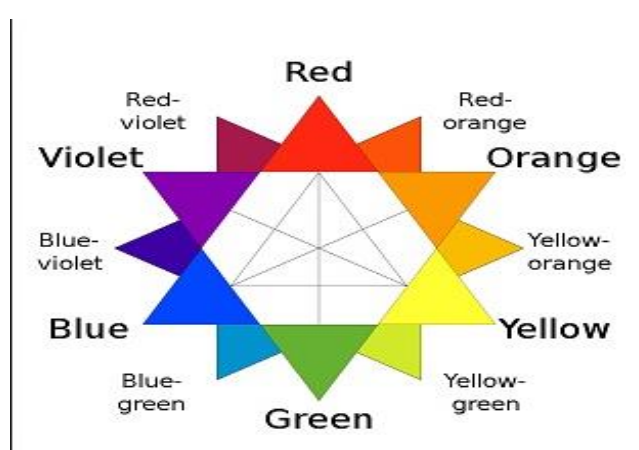

Contoh Karya Teori Warna: Warna Primer, Sekunder dan tersier (Berwarna)

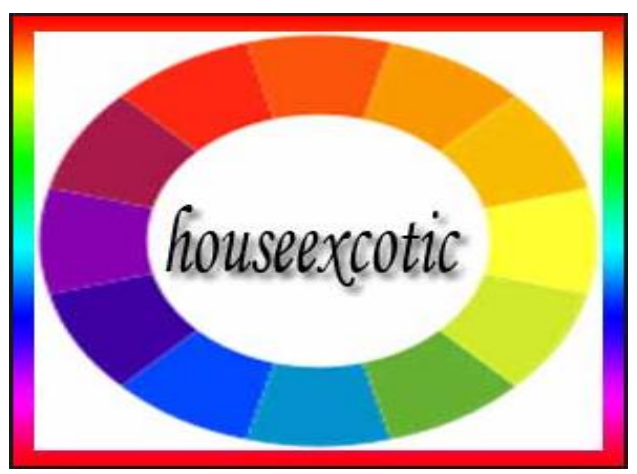

Vol.1 No.1 - Agustus 2015 
Contoh Karya: Panas Dinginnya Warna (Berwarna)
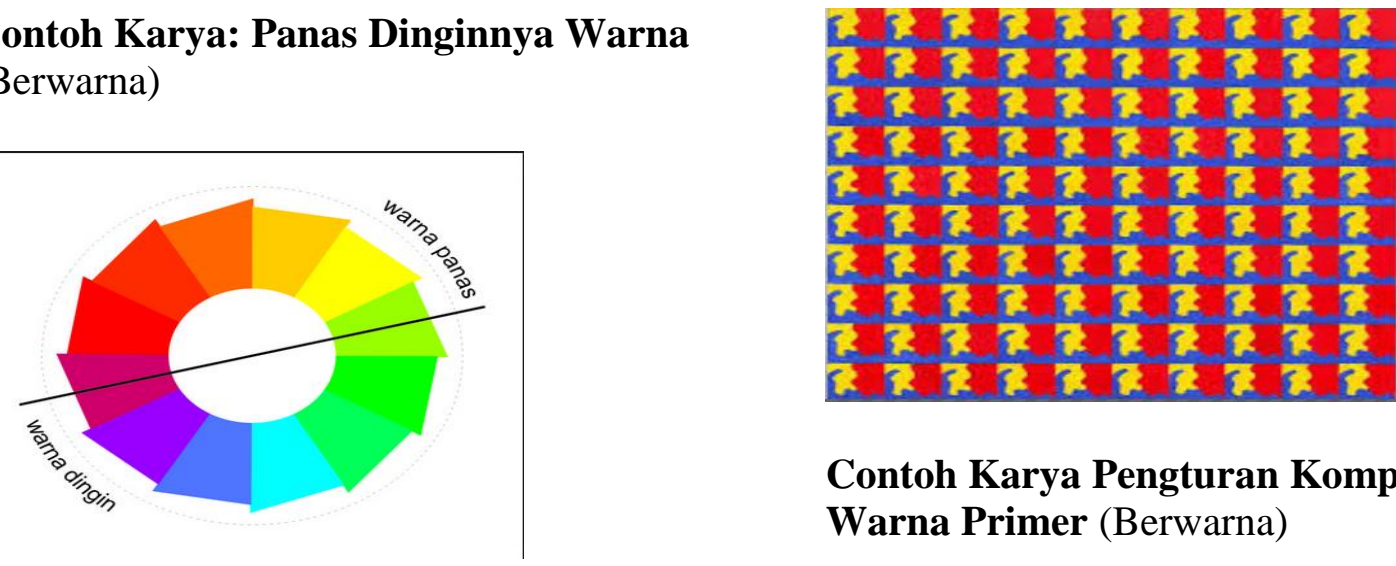

Contoh Karya Pengturan Komposisi Warna Primer (Berwarna)

Contoh Karya Teori Warna: Lingkaran Warna Primer (Berwarna)
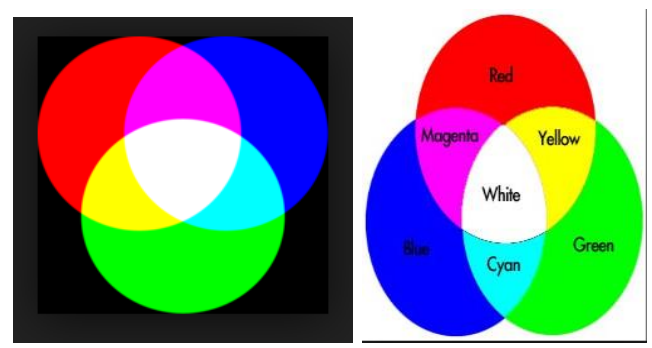

Contoh Karya Tingkatan Warna-warna Primer (Berwarna)

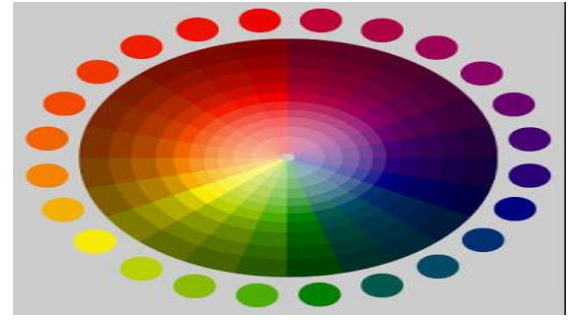

Contoh Karya Pengturan Komposisi Warna Primer (Berwarna)

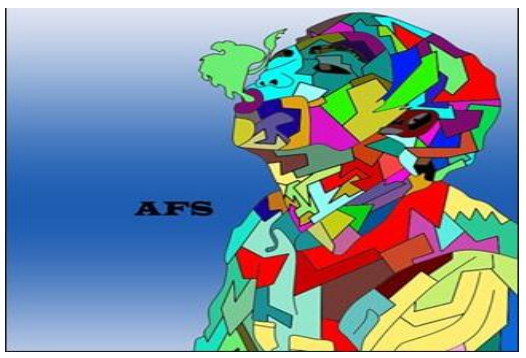

Contoh Karya Pengturan Komposisi Warna Primer (Berwarna)

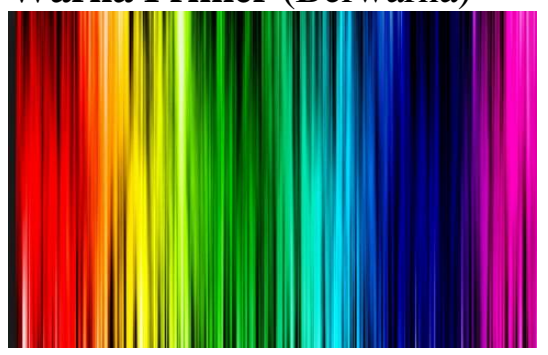

Contoh Karya Pengturan Komposisi Warna Primer (Berwarna)

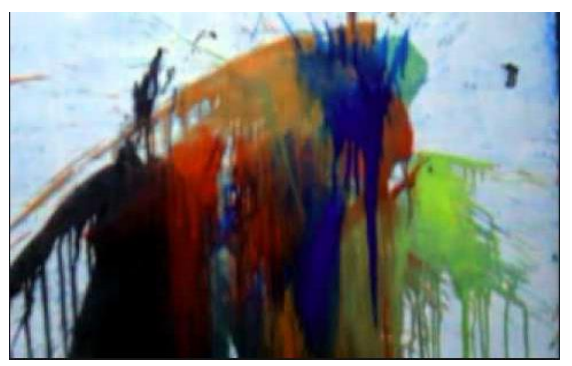

Vol.1 No.1 - Agustus 2015 


\section{Contoh Karya Desaion Jeket (Berwarna)}
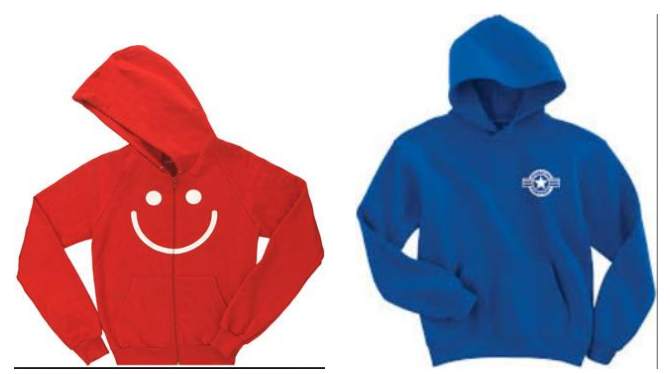

\section{Contoh Karya Kreatifitas dasar-dasar} Perancangan (Berwarna)
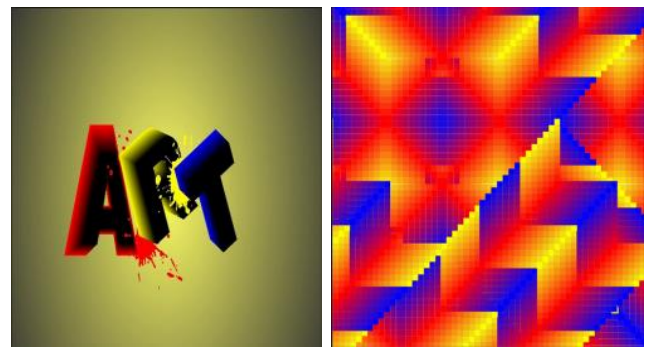

\section{Contoh Karya Kreatifitas Warna Kesan} Tiga Dimensi (Berwarna)
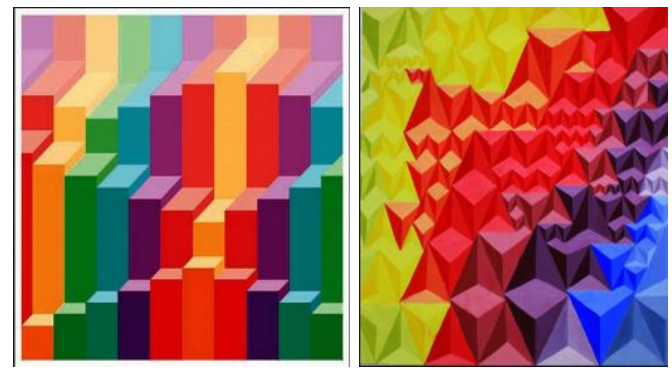

\section{Kesimpulan}

Nirmana berarti kosong atau tidak ada apaapa dan bisa juga berarti abstrak atau tidak bermakna. Kalimat tersebut merupakan sebuah ungkapan, bahwa pada awalnya, sebelum seseorang bertindak menciptakan sesuatu, masih belum ada apa-apa atau belum ada makna dari segala sesuatu. Hal tersebut kemudian di jadikan titik awal atau merupakan pelajaran yang harus dikuasai oleh seseorang yang ingin belajar tentang desain sebelum mulai berkarya. nirmana mengajarkan tentang unsur atau elemen yang ada pada suatu lukisan atau gambar serta estetika seni dalam mengorganisasi unsur atau elemen agar menjadi sebuah karya rupa yang bukan saja bagus, tetapi juga bermakna.

Dengan mempelajari nirmana, seseorang diharapkan akan memiliki pengertian, dapat mengasah ketrampilan, dan mempertajam kepekaan terhadap segala sesuatu yang menyangkut dunia desain. Bahkan tipografi juga akan dikembangkan dari nirmana. Oleh karena itu, nirmana wajib dipelajari dengan melakukan banyak latihan secara continyu untuk dapat menghayati seni rupa dan seni desain dengan baik. Bahkan mungkin di saat mempelajarinya akan terambah pula pula cabang seni yang lain. Di dalam nirmana, seseorang akan mempelajari segala sesuatu yang berhubungan dengan seni rupa dan desain melalui tahap-tahap yang sangat mendasar. Desain dikembangkan dari seni rupa sesuai tuntutan kegunaannya. Sehingga yang dipelajari pada awalnya akan menentukan kualitas kinerja ciptaan karya seni atau rancangan karya seni terap berikutnya.

Semoga artikel ini dapat dijadijan referensi dan sebagai pedoman pembelajaran maupun kinerja dalam membuat desain atau karya seni kainnya.

Khususnya dari kami selaku penulis artikel sangat mengharapkan Bila ada yang ditanyakan, saran, tanggapan dan ide kreatif silakan isi pada komentar, saya akan mencoba menjawab secepat dan sebaik mungkin.

\section{Vol.1 No.1 - Agustus 2015}




\section{DAFTAR PUSTAKA}

1. Indrajaya, F. (2013). Uebermensch sebagai Radikalisasi Filsuf Alamiah (Krisis Pelampauan

2. Diri dalam Dunia Pendidikan Desain). Jurnal Humaniora: Language, People, Art, and Communication Studies. 4(2): 11661175.

3. Kemmis, S., McTaggart, R. (1988). The action research planner. Victoria: Deakin University.

4. Lester, P. M. (2006). Visual Communication: Images with Message. Toronto: Thomson Wadsworth Publishing.

5. Maryunis, A. (2003). Usage of information mapping to stimulate learning process and outcomes of strategized teachings of mathematics. Education Journal. 26 (2).

6. Poulin, R. (2011). The Language of Graphic Design: An Illustrated Handbook for Understanding Fundamental Design Principles. New York: Rockport Publishers.

7. Santoso, S. (2000). Problematik Pendidikan dan Cara Pemecahannya. Jakarta: Kreasi Pena Gading.

Vol.1 No.1 - Agustus 2015 